\title{
La ejecución de sentencias sigue siendo un auténtico quebradero de cabeza veinte años después de la aprobación de la LJCA
}

\author{
Juan Ramón Fernández Torres \\ Catedrático de Derecho Administrativo \\ Universidad Complutense de Madrid
}

Abogado

\begin{abstract}
SUMARIO: I. INTRODUCGIÓN. II. EL PAPEL GRIS DE LA LEYJURISDICGIONAL DE 1956. III. LA LEY JURISDICCIONAL DE 1998: BALANCE GENERAL MUY INSATISFACTORIO DESDE LA PERSPECTIVA DELJUSTICIABLE. IV. PERSPEGTIVAS DE FUTURO.
\end{abstract}

RESUMEN: el presente estudio da cuenta de las limitaciones y disfunciones tales como la ausencia de regulación de un verdadero proceso ejecutivo; la defectuosa técnica normativa empleada por la LJCA al abordar la materia; la pervivencia de privilegios administrativos de origen francés y justificación más que cuestionable; las dificultades de diverso tipo suscitadas por la imposibilidad legal o material de ejecución de sentencias contemplados en el artículo 105.2 LJCA, a las que se suman en sectores paradigmáticos como el urbanismo. El autor propone medidas como la erradicación de la acción pública a la vista la extraordinaria amplitud de la legitimación activa con fundamento en el artículo $24 \mathrm{CE}$; la depuración de los privilegios antedichos que carecen de justificación objetiva; la atribución a los Jueces y Tribunales de una potestad para suspender la tramitación del proceso contencioso-administrativo y otorgar un plazo para intentar la subsanación del vicio constatado, cuando ello sea posible; y el reconocimiento expreso de instrumentos tales como el principio de intangibilidad de la obra pública.

PALABRAS CLAVE: ejecución de sentencias. Problemas y perspectivas. Reforma de la LJCA.

ABSTRACT: the present study accounts for the limitations and dysfunctions such as the absence of regulation of a true executive process; the defective normative technique employed by the Administration Judicial Review Act in approaching the subject; the survival of administrative privileges of French origin and justification beyond question; the difficulties of various kinds arising from the 
cases of legal impossibility or material execution of sentences contemplated in Article 105.2 Administration Judicial Review Act, which are added in paradigmatic sectors such as urbanism. The author proposes measures such as the eradication of public action, in view of the extraordinary breath of active legitimization based on Article 24 of Spanish Constitution; the debugging of the aforementioned privileges that lack objective justification; the attribution to the Judges and Courts of a power to suspend the processing of the contentious-administrative process and to grant a period of attempt the rectification of the observed defect, whenever possible; the express recognition of instruments such as the principle of intangibility of public works.

KEY WORDS: execution of sentences. Problems and perspectives. Reform of the Administration Judicial Review Act

\section{INTRODUGGIÓN}

Hace ahora sesenta y dos años la extraordinaria Exposición de Motivos de la Ley reguladora de la Jurisdicción Contencioso-Administrativa de 27 de diciembre de 1956 acertaba a definir de forma impecable el papel confiado al proceso, declarando que "la necesidad de una Jurisdicción contenciosa-administrativa eficaz trasciende de la órbita de lo individual y alcanza al ámbito colectivo. Porque las infracciones administrativas se muestran realmente no tan sólo como una lesión de las situaciones de los administradores, sino como entorpecimiento a la buena y recta administración" (sic).

Pese a tan nobles propósitos, éstos distan muy mucho de cumplirse ni entonces, ni años después. Es ilustrativo el testimonio del entonces Magistrado del Tribunal Supremo J. Fernández Hernando que, tras exponer en detalle las diversas modalidades de incumplimiento de las sentencias dictadas por los Tribunales contencioso-administrativos, concluye con un elocuente llamamiento a los mismos para poner fin a un estado de cosas muy insatisfactorio. Lo hace en términos singulares pero muy expresivos: "la ardua empresa de someter al juego limpio de las normas jurídicas al complejo vivo de las relaciones humanas, de tender un puente practicable entre el sollen y el sein kelsenianos, impone a los Jueces «una esclavitud honrosa, mas al fin esclavitud», según escribió el P. Feijoo, que se traduce en solícita dedicación a su noble oficio a fin de alcanzar la Justicia con el ineficiente concurso de la Prudencia y de la Fortaleza. Luzcan estas virtudes en el diario afán de los que integran los Tribunales encargados de fiscalizar la actividad de la Administración pública proclive a 
desorbitar sus potestades con agravio de derechos y lesión de intereses individuales, y todo lo demás - eficacia, prestigio, acatamiento - les será dado por añadidura"1.

Estas palabras no han perdido un ápice de vigencia. En absoluto pueden ser tildadas de obsoletas, como habrá ocasión de comprobar al examinar el balance de dos décadas de vigencia de la Ley 29/1998, de 13 de julio, reguladora de la Jurisdicción Contenciosa-Administrativa (LJCA, en adelante). En el fondo, son previsibles si se examina la evolución de la Jurisdicción contencioso-administrativa y se tiene presente que, como indica el Profesor Font i Llovet, "la historia de la ejecución de las sentencias contencioso-administrativas es la historia de un lamento... prolongado, sentido directamente por los abogados y expuesto por los juristas, un lamento objeto de crónica fiel por la doctrina científica que se añade al lamento mismo. Y lo que es más significativo, lamento también por parte de los jueces y tribunales"2.

Pero antes conviene recordar algunas ideas elementales sobre la Ley Jurisdiccional de 1956, a modo de preámbulo.

\section{EL PAPEL GRIS DE LA LEY JURISDICGIONAL DE 1956}

Es de sobra conocido que la Ley reguladora de la Jurisdicción Contencioso-Administrativa de 1956 realiza notables avances en distintos campos ${ }^{3}$. Pero también es sabido que no logra deshacerse de dogmas tradicionales tales como la separación de poderes, fundamento del otorgamiento de la competencia inicial para la ejecución

1 Vid. FERNÁNDEZ HERNANDO, J., "El incumplimiento de las sentencias administrativas, sus formas y su tratamiento jurisprudencial", en AAVV, Estudios en homenaje a fordana de Pozas, Tomo III, vol. $1^{\circ}$. Estudios de Derecho Administrativo general, Instituto de Estudios Políticos, Madrid, 1961, págs. 239-253 y, en especial, pág. 253.

2 Vid. el prólogo a la obra de MARTÍN DELGADO, I., Función jurisdiccional y ejecución de sentencias en lo contencioso-administrativo. Hacia un sistema de ejecución objetivo normalizado, Marcial Pons, Madrid, 2005, pág. 9.

3 Vid. una aproximación a la misma, así como referencias bibliográficas esenciales, en FERNÁNDEZ TORRES, J.R., Historia legal de la furisdicción contencioso-administrativa (1845-1998), Iustel, Madrid, $1^{\text {a }}$ ed., 2007, págs. 801 y ss.; y, recientemente, BASSOLS COMA, M., "A propósito del sexagésimo aniversario de la Jurisdicción contencioso-administrativa de 1956: modificaciones e innovaciones introducidas en su tramitación parlamentaria”, Revista de Administración Pública (2017), 203, págs. 309-341, incluido asimismo en MÍGUEZ MACHO, L. y ALMEIDA CERREDA, M. (coordinadores), Los retos actuales del Derecho Administrativo en el Estado autonómico. Estudios en homenaje al Profesor Fosé Luis Carro Fernández-Valmayor, EGAP, Andavira y Fundación Democracia y Gobierno Local, Santiago de Compostela, 2017, vol. II, págs. 27-50. 
de las sentencias a la Administración autora del acto recurrido (artículo 103) ${ }^{4}$, y la inembargabilidad de los caudales públicos (artículo 108) .

Es notorio, además, que la Ley Jurisdiccional de 1956 no impone el cumplimiento inexorable, íntegro y total de las sentencias, toda vez que contempla la posibilidad en supuestos tasados de suspenderlas o inejecutarlas mediante acuerdo del Consejo de Ministros (artículo 105). Los propios Magistrados del orden contencioso-administrativo reconocen dichas limitaciones ${ }^{6}$, junto a una doctrina científica ${ }^{7}$ que las denuncia con insistencia.

A todo ello se une que la Ley Jurisdiccional de 1956 no frena de forma eficaz las inercias del pasado y las prácticas abusivas de las Administraciones condenadas, a pesar de la introducción de una diversidad de mecanismos, tales como el otorgamiento a los Jueces y Tribunales de poderes de impulso e intimación de la ejecución (artículo 110), la proclamación de la responsabilidad, personal y directa, civil y penal, de los agentes encargados del cumplimiento de las Sentencias (artículo 105.6) o la publicación en el Boletín Oficial del Estado de una relación expresiva de las ejecutadas

4 Hace más de cuarenta y cinco años el Magistrado de lo Contencioso-administrativo CANO MATA, A., afirmaba de forma categórica que "el sistema de ejecución que contempla dicha Ley es peligroso e inadecuado, pues no basta con que el tribunal tenga en sus manos medidas fiscalizadoras, sino que es necesario que sea él mismo quien ejecute las sentencias convirtiendo la Administración en una simple ejecutor «cualificado»" [vid. "Ejecución judicial de las resoluciones contencioso-administrativas", Revista de Administración Pública (1973) 70, págs. 29-53]. Una década después vuelve sobre el mismo asunto declarando de forma categórica que, "sin este sometimiento absoluto, la justicia contencioso-administrativa puede llegar a ser un espejismo, puesto que si - como dijo MERKL- el proceso contencioso supone un voto de desconfianza para la Administración y de confianza para la Justicia, ¿no será la ejecución administrativa un desprecio hacia la justicia y un privilegio innecesario de la Administración" [vid. "Ejecución judicial de sentencias contencioso-administrativas. El embargo a la Administración como manifestación del principio de tutela judicial efectiva", Revista de Administración Pública (1984) 103, págs. 17-45, en especial pág. 22].

GARCÍA DE ENTERRÍA, E., lo calificaba hace ahora más de treinta años como un "asombroso fósil medieval viviente fuera de su medio" [vid. "Los postulados constitucionales de la ejecución de las sentencias", Documentación Administrativa (1987) 209, págs. 7-15, en detalle pág. 13; y apenas cuatro años antes, CANO MATA, A. (1984: 41-45)].

Vid., por todos, GABALDÓN PÉREZ, J., 'La ejecución de las sentencias contencioso-administrativas", Poder Fudicial (1990) 15, número extraordinario dedicado a la reforma del proceso contencioso-administrativo, págs. 27-58; y GONZÁLEZ RIVAS, J.J., 'Reforma de la Ley de la Jurisdicción Contencioso-Administrativa: urgencia y criterios orientadores de la reforma", Poder fudicial (1990) 15, número extraordinario dedicado a la reforma del proceso contencioso-administrativo, págs. 155-182.

Vid., p.e., BORRAJO INIESTA, I., "Las facultades de los Tribunales para ejecutar sentencias contra las Administraciones públicas (Auto del Tribunal Supremo 13 marzo 1986, alcalde de Villanueva de Arosa)", Revista Española de Derecho Administrativo (1987) 53, págs. 62-96; BASSOLS COMA, M., "La ejecución de sentencias condenatorias de la Administración Pública en jurisdicciones distintas a la contencioso-administrativa", en GÓMEZ FERRER MORANT, R., (coordinador), Libro homenaje al Profesor Fosé Luis Villar Palasí, Civitas, Madrid, 1989, págs. 109-131, así como en Documentación Administrativa (1987) 209, págs. 47-97; y SOSA WAGNER, F. y QUINTANA LÓPEZ, T. "La ejecución de las sentencias contencioso-administrativas", Documentación Administrativa (1987) 209, 17-45. 
durante el año anterior, así como de las inejecutadas y los motivos de ello (artículo 112). Dan fe de lo señalado una multitud de testimonios de profesores, magistrados y abogados, además del antes citado de J. Fernández Hernando. Las críticas formuladas se refieren, por supuesto, a la regulación legal ${ }^{8}$ y, además, y sobre todo, a la propia actitud exhibida por los órganos jurisdiccionales, que está muy lejos de las expectativas generadas por la propia Ley Jurisdiccional de $1956^{9}$.

En efecto, la clave de la falta de operatividad real del sistema de ejecución de sentencias de la Ley Jurisdiccional de 1956 no se halla tanto en sus limitaciones cuanto que en su aplicación práctica o, incluso, en su inaplicación: "el rendimiento hasta ahora obtenido del cuadro legal que se contiene en los artículos 103 y siguientes de nuestra Ley jurisdiccional - afirma T. R. Fernández Rodríguez- es más bien escaso. Parece claro, también, que una utilización a fondo de los mecanismos legales disponibles sería capaz de reducir a la nada todos los problemas. La cuestión para nosotros no está, por lo tanto, en una reforma de la legislación vigente, ni en una conversión del actual sistema de ejecución administrativa bajo fiscalización judicial por otro de ejecución judicial a través de la Administración, sino en la afirmación por parte de los Tribunales de una voluntad decidida de poner en juego unas técnicas jurídicas que, en uno y todo caso, son muy similares y que, desde luego, no funcionan solas, ni funcionan mejor por el simple hecho de cambiar la rúbrica que los preside" ${ }^{" 10}$.

8 Ya en la $1^{\text {a }}$ edición del "Curso de Derecho Administrativo" los Profesores García de Enterría y Fernández Rodríguez advertían que encomendar la ejecución de la sentencia a la propia Administración condenada "implica dejar en sus manos el cumplimiento de las sentencias que la sean desfavorables, con lo cual amenaza con quedar en el aire todo el sistema de garantías que la existencia de la vía contencioso-administrativa supone" (vid. GARCÍA DE ENTERRÍA, E. y FERNÁNDEZ RODRÍGUEZ, T.R., Curso de Derecho Administrativo, Civitas, Madrid, volumen II, $1^{\text {a }}$ ed., 1977, pág. 546). En términos más condescendientes se pronuncia GONZÁLEZ PÉREZ, J. (vid. "Derecho procesal administrativo", tomo II, IEP, Madrid, $2^{a}$ ed., 1966, págs. 955 y 956).

9 Vid. p.e., GONZÁLEZ PÉREZ, J., “Administración Pública y libertad”, UNAM, Méjico, 1971, págs. 81 y ss.; MARTÍN-RETORTILLO BAQUER, L. "Ejecución de sentencia del Tribunal de lo Contencioso-Administrativo: ¿Puede un Ayuntamiento demorarla o desviarla de alguna manera?", Revista de Administración Pública (1972) 67 págs. 231-239; DE LA OLIVA SANTOS, A., "Notas sobre la ejecución de sentencias en el proceso administrativo", Documentación Administrativa (1974) 159, págs. 75-111; FERNÁNDEZ RODRÍGUEZ, T.R., "Algunas reflexiones sobre las formas indirectas de incumplimiento por la Administración de las sentencias de los Tribunales de la Jurisdicción contenciosa-administrativa", Revista de Administración Pública (1974) 73, págs. 151-177; o GONZÁLEZ MARIÑAS, P., La inejecución de sentencias de los Tribunales Contencioso-Administrativos, ENAP, Madrid, 1975; entre otros. En esta línea, el Magistrado CANO MATA, A. enfatiza con apoyo en el derecho fundamental a la tutela judicial efectiva reconocido por el artículo $24 \mathrm{CE}$ lo que llama "un principio inexorable: cuando la Administración retrase el cumplimiento de las medidas conducentes a la ejecución de una sentencia, el tribunal tiene que adoptar todas las necesarias -repetimos, todas- para que el principio de tutela efectiva no sea violado" (vid. 1984: 41).

10 Vid. FERNÁNDEZ RODRÍGUEZ, T.R., "De nuevo sobre la ejecución de sentencias contencioso-administrativas", Revista de Administración Pública (1977) 84, págs. 263-278. 
Ello explica que la doctrina científica denuncie su falta de acomodo a exigencias constitucionales básicas ${ }^{11}$ y "la propia precariedad del sistema de ejecución de sentencias, que, aun habiendo sido objeto de una importante reconstrucción por vía interpretativa, apenas podía satisfacer los requerimientos constitucionales, particularmente exigentes en este punto" ${ }^{\prime 2}$.

\section{LA LEY JURISDICGIONAL DE 1998: BALANCE GENERAL MUY INSATISFACTORIO DESDE LA PERSPECTIVA DEL JUSTICIABLE}

En este contexto, la superación decidida de los viejos dogmas y el esfuerzo de adaptación a la Constitución Española por la LJCA constituyen una prioridad del legislador en 1998. No en balde la Exposición de Motivos de la LJCA declara que "la Ley ha realizado un importante esfuerzo para incrementar las garantías de ejecución de las sentencias, desde siempre una de las zonas grises de nuestro sistema contencioso-administrativo" (sic).

Semejante planteamiento legal es acogido favorablemente en primera instancia por la doctrina científica, que no duda en afirmar que el sistema de ejecución de sentencias recogido en la misma merece ser calificado "como uno de sus mayores aciertos" $" 13$.

11 Vid., p.e., GARCÍA DE ENTERRÍA, E. (1987: 7-15); FONT I LLOVET, T., La ejecución de las sentencias contencioso-administrativas. Aspectos constitucionales, Civitas, Madrid, 1985; del mismo autor, "Medidas para hacer efectiva la ejecución de las sentencias", en MARTIN-RETORTILLO BAQUER, L.(coordinador), La protección jurídica del ciudadano (procedimiento administrativo y garantía jurisdiccional). Estudios en homenaje al Profesor Fesús González Pérez, volumen II. "La Jurisdicción contencioso-administrativa, Civitas, Madrid, 1993, págs. 1173-1186; BELTRÁN DE FELIPE, M., "Las exigencias constitucionales de una nueva concepción del contencioso-administrativo", en MARTIN-RETORTILLO BAQUER, S.(coordinador), Estudios sobre la Constitución Española. Homenaje al Profesor Eduardo García de Enterría, volumen IV, "Del Poder Fudicial. Organización territorial del Estado", Civitas, Madrid, 1991, págs. 2085-3111, en especial, págs. 3102-3108; del mismo autor, El poder de sustitución en la ejecución de las sentencias condenatorias de la Administración, Civitas, Madrid, 1995; y, acerca de la doctrina elaborada por el Tribunal Constitucional en la materia, RODRÍGUEZ-ZAPATA PÉREZ, J., "Ejecución de sentencias contencioso-administrativas y Tribunal Constitucional", en SÁNCHEZ LAMELAS, A.(coordinadora), La ejecución de sentencias contencioso-administrativas: IV curso sobre la jurisdicción contencioso-administrativa, Aranzadi Thomson, Pamplona, 2006, págs. 13-32.

12 Vid. GARCÍA DE ENTERRÍA, E. y FERNÁNDEZ RODRÍGUEZ, T.R., Curso de Derecho Administrativo, Civitas Thomson Reuters, Madrid, volumen II, 15 a ed., 2017, pág. 603. Abunda en esta misma línea GONZÁLEZ PÉREZ, J., para quien "los Tribunales contencioso-administrativos, como en tantas otras ocasiones, no aprovecharon la importantísima innovación legislativa y continuaron actuando -hasta la Constitución de 1978- como si carecieran de potestades de ejecución frente a las Entidades públicas" (vid. Comentarios a la Ley de la furisdicción contencioso-administrativa, Civitas Thomson Reuters, Madrid, 6a ed., 2011, pág. 1024).

13 Vid., p.e., GARGÍA DE ENTERRÍA, E. y FERNÁNDEZ RODRÍGUEZ, T.R., (2017: 695); en la misma línea, ARNALDO ALCUBILLA, E. y FERNÁNDEZ VALVERDE, R., furisdicción Contencio- 
Sin embargo, este parecer ni fue unánime en su día, ni lo es en la actualidad ${ }^{14}$. Más bien al contrario. Existen limitaciones y disfunciones, así como obstáculos y frenos que lastran la observancia del mandato constitucional de cumplimiento de las resoluciones judiciales y, por ende, la efectividad del derecho fundamental a la tutela judicial ${ }^{15}$, dificultando e incluso imposibilitando que "esta tutela sea real y verdadera y no meramente nominal o, dicho de otro modo, cuando real y verdaderamente, no sólo nominalmente, se resuelva el conflicto planteado o se actúe el derecho o se satisfaga la pretensión"16.

Sin ánimo de exhaustividad, mi propósito es dar cuenta de las limitaciones y disfunciones, así como de los obstáculos y frenos que son más habituales y, por ello mismo, más controvertidos ${ }^{17}$. En primer lugar, debe señalarse la ausencia de regula-

so-Administrativa. Comentarios a la Ley 29/1998, de 13 de julio, Reguladora de la furisdicción Contencioso-Administrativa, La Ley y El Consultor, Madrid, $3^{\text {a }}$ ed., 2007, págs. 932 y ss.; FONT I LLOVET, T., "Justicia administrativa y ejecución de sentencias", en MONTORO CHINER, M. J., (coordinadora), La justicia administrativa: libro homenaje al Profesor Doctor D. Rafael Entrena Cuesta, Atelier, Barcelona, 2003, págs. 819-842; TORNOS MAS, J., BAÑO LEÓN, J.M., LOZANO CUTANDA, B., MÍGUEZ BEN, E., BELTRÁN DE FELIPE, M. o GÓMEZ PUENTE, M., en AAVV, "Comentarios a la Ley de la furisdicción Contencioso-Administrativa”, Civitas, Madrid, 1998, págs. 715 y ss.; MARTÍN REBOLLO, L., 40 años de Derecho Administrativo post constitucional y otros ensayos rescatados, Aranzadi Thomson Reuters y Gobierno de Cantabria, Pamplona, 2017, págs. 603 y ss.; ORTEGA ÁLVAREZ, L., "La ejecución de sentencias", Justicia Administrativa (1999), número extraordinario consagrado a La Ley de la furisdicción contenciosa-administrativa, págs. 153-163; del mismo autor, "La ejecución de sentencias", en LEGUINA VILLA, J. y SÁNCHEZ MORÓN, M. (directores), Comentarios a la Ley de la furisdicción contencioso-administrativa, Lex Nova, Valladolid, 1999, págs. 481-501; SALA, P., XIOL RÍOS, J.A. y FERNÁNDEZ MONTALVO, R., Práctica procesal contencioso-administrativa, tomo VII. Ejecución de sentencias (Artículos 103 a 113 LJCA), Bosch, Barcelona, 1999; SENÉN HERNÁNDEZ, M., "Capítulo 12. Ejecución de sentencias" en PENDÁS GARCÍA, B., (coordinador), Ley de la furisdicción contencioso-administrativa. Estudio sistemático, ed. Praxis, S.A., Madrid, 1999, págs. 367-400; y TORNOS MAS, J. "Comentario al Capítulo IV del Título IV de la LJCA”, en SANTOS VIJANDE, J. Mª (director), Comentarios a la Ley de la furisdicción contencioso-administrativa (Ley 29/1998, de 13 de julio), EDERSA, Madrid, 1999, págs. 825-883.

14 Vid., por todos, SANTAMARÍA PASTOR, J.A., La Ley reguladora de la Furisdicción Contencioso-Administrativa. Comentario, Iustel, Madrid, $1^{\mathrm{a}}$ ed., 2010, págs. 1085 y ss.

15 Vid., p.e., MARTÍN VICTORIA, S. Ma ., La furisdicción Contenciosa: Análisis Práctico, Aranzadi Thomson Reuters, Pamplona, $1^{\text {a }}$ ed., 2016, págs. 881 y ss.

16 Vid. DELGADO BARRIO, J., "El principio de efectividad de la tutela judicial en la jurisprudencia contenciosa-administrativa", en MARTIN-RETORTILLO BAQUER, L., (coordinador), La protección jurídica del ciudadano (Procedimiento administrativo y garantía jurisdiccional). Estudios en homenaje al Profesor Fesús González Pérez, volumen II. La Jurisdicción contenciosa-administrativa, Civitas, Madrid, 1993, págs. 1187-1224, en particular pág. 1190.

17 Dejo al margen otras formas de inejecución administrativa, como las consistentes en la inactividad que pretende evitar el cumplimiento de sus propios actos [vid., al respecto, LÓPEZ BENÍTEZ, M., "Furisdicción contencioso-administrativa e inejecución por la Administración de sus actos firmes (comentario a la Sentencia del Tribunal Supremo de 20 de junio de 2005, recurso de casación núm. 3100/2003)”, en GARCÍA DE ENTERRÍA, E. y ALONSO GARCÍA, R. (coordinadores), Administración y Justicia. Un análisis jurisprudencial. Liber amicorum Tomás-Ramón Fernández, volumen I. España, Civitas Thomson Reuters, Madrid, 1ª ed., 2012, págs. 15191544], así como supuestos excepcionales y especialmente complejos, como el expuesto por FORTES MAR- 
ción de un verdadero proceso ejecutivo. En puridad, hay autores como J. González Pérez que sostienen que en buena lógica lo razonable era la implantación pura y simplemente de una vía ejecutiva para tales supuestos. A su juicio, "si ante la inactividad de la Administración lo que se pretende es una actividad material, un dar o hacer, no tendría sentido seguir todos los trámites del proceso administrativo declarativo hasta la sentencia cuando, por existir ya un título ejecutivo con fuerza obligatoria, lo que se pretende de la Administración no es la sentencia de condena, sino la ejecución. Por lo cual lo que impondría la tutela jurisdiccional efectiva sería arbitrar un proceso administrativo ejecutivo en el que, dando por supuesta la obligación de hacer, la tramitación tratara de hacer efectiva la realización de aquella actividad"18.

Tanto es así que algún autor llega a afirmar que "sólo haciendo gala de una generosidad o un esfuerzo imaginativo sin límites puede hablarse de ejecución de sentencias en el ámbito contencioso-administrativo, sobre todo si se compara le extensa y detallada regulación contenida en la Ley 1/2000 de Enjuiciamiento Civil con los escuetos, rácanos y muy deficientes diez artículos que la Ley 29/1998 de 13 de julio dice dedicar a la materia"'

En segundo lugar, debe resaltarse la defectuosa técnica normativa empleada por la LJCA al abordar la materia. Algún autor va mucho más allá, poniendo en cuestión el mismo punto de partida de la ordenación positiva, como es la presunción del cumplimiento voluntario de la Sentencia por la Administración condenada y, en caso contrario, la suficiencia de la admonición del juez o Tribunal para vencer su resistencia. De ahí que, como resultado de la comparación entre los regímenes civil y contencioso-administrativo de ejecución de sentencias, se eleven voces en la propia Magistratura que sostienen que "esta diferencia de planteamientos pone en evidencia

TÍN, A., [vid. "La cuadratura del círculo o la imposible ejecución total de la Sentencia del caso «Ciudad Santo Domingo-aeropuerto de Madrid/Barajas» (estudio de las Sentencias del Tribunal Supremo de 15 de abril de 2011 )", en GARCÍA DE ENTERRÍA, E. y ALONSO GARCÍA, R. (coordinadores), Administración y Justicia. Un análisis jurisprudencial. Liber amicorum Tomás-Ramón Fernández, volumen I. España, Civitas Thomson Reuters, Madrid, $1^{\text {a }}$ ed., 2012, págs. 1157-1191]. Por cierto, el Auto del Tribunal Superior de Justicia de Madrid de 30 de julio de 2018 (DF n 109/2004) acordó declarar ejecutada la Sentencia del Tribunal Supremo de 13 de octubre de 2008, al estimar que en los informes llevados a cabo acerca de las mediciones del ruido producido por el sobrevuelo de aeronaves sobre la urbanización Santo Domingo de Madrid "se aprecia una contaminación acústica por debajo de los límites legales establecidos en las normas vigentes".

18 Vid. GONZÁLEZ PÉREZ, J. (2011: 406).

19 Vid. PÉREZ ALONSO, J., "La ineficacia del sistema de ejecución de sentencias contencioso-administrativas; reflexiones a raíz de la legislación, la jurisprudencia. La realidad cotidiana: ejemplos prácticos de modelos en inejecución de sentencias", Revista General de Derecho Administrativo (2015) 40, págs. 1-2 y 8. Sin llegar a esa valoración tan crítica, BAÑO LEÓN J. M . critica la ausencia de un proceso de ejecución diáfano como consecuencia de la superposición disfuncional de reglas y mecanismos [vid. BAÑO LEÓNJ. Ma " "La eficacia de las sentencias contra la Administración o la claudicación del Estado de Derecho", Revista Española de Derecho Administrativo (2016) 177, pág. 86]. 
que la Ley Jurisdiccional no está pensada para situaciones complejas. Parece que la idea de la que parte es que la ejecución de la sentencia por la Administración no plantea problemas, a lo sumo una cierta resistencia pasiva que puede ser vencida con una ligera presión ejecutiva" ${ }^{20}$.

En tercer lugar, es objeto de crítica igualmente la pervivencia de privilegios administrativos de origen francés y justificación más que cuestionable. Me refiero a privilegios tales como

- la inembargabilidad de los caudales públicos ${ }^{21} \mathrm{y}$, muy en particular, la regla contenida en el artículo 106.4 LJCA. En la medida en que dicho precepto faculta a la Administración condenada al pago de una cantidad a poner en conocimiento del Juez o Tribunal un hipotético "trastorno grave a su Hacienda" que se derivaría del cumplimiento de la sentencia ("habría de producir"), acompañado de una propuesta razonada, con el fin de que, previa audiencia a las partes "resuelva sobre el modo de ejecutar la sentencia en la forma que sea menos gravosa para aquélla", está haciendo posible un cumplimiento gradual y diferido ${ }^{22}$. Ello implica la imposición al recurrente ganador de un deber de financiación a la Administración condenada, que se ha de sumar a los onerosos gastos a los que ha debido hacer frente hasta obtener la firmeza de la Sentencia estimatoria (la ejecución del acto recurrido, ya sea una sanción pecuniaria, ya la liquidación de un tributo, o ya el cumplimiento de una orden -p.e., urbanística de conservación o ejecución de obras-, las tasas y gastos judiciales y los honorarios de procurador y abogado, en todo caso). Como advierten los Profesores E. García de Enterría y T.R. Fernández, "esto supone gravar al acreedor ejecutante con un préstamo forzoso a la Administración ejecutada. Lo lógico sería que ésta negocie en el mercado ese préstamo y pague su deuda con el importe del mismo. En último extremo, lo que es evidente es que esta fórmula arcaica, de ser aplicada, deberá ser compensada en términos reales de perjuicio, según el mercado y la situación particular del ejecutante, sin que los tipos legales puedan jugar más que como una simple referencia"'23.

20 Vid. PARICIO RALLO, E., "La insolvencia de la Administración. Ejecución judicial de deudas públicas", Cuadernos de Derecho Local (2012) 30, pág. 6.

21 Ello es así, a pesar de la positiva consideración de ampliables "siempre" de los créditos presupuestarios a los fines de la ejecución de las sentencias condenatorias al pago de cantidades líquidas (artículo 106.1 LJCA), que impide la invocación abusiva por las Administraciones condenadas de su insuficiencia. Vid. AAVV., "Comentarios a la Ley de la furisdicción Contencioso-Administrativa de 1998", Aranzadi Thomson Reuters, Pamplona, 4 ed., 2010, pág. 1094; y RUIZ OJEDA, A., "La ejecución de condenas pecuniarias y el embargo de dinero y bienes de la Administración tras la nueva Ley de lo Contencioso y la Sentencia 166/1998, del Tribunal Constitucional”, Revista Española de Derecho Administrativo (1999) 103, págs. 423-449.

22 GARCÍA DE ENTERRÍA, E. y FERNÁNDEZ RODRÍGUEZ, T.R. lo denominan "aplazamiento escalonado de los pagos" (2017: 705).

23 Vid. GARCÍA DE ENTERRÍA, E. y FERNÁNDEZ RODRÍGUEZ, T.R. (2017: 705). 
- los plazos voluntarios de cumplimiento de los fallos (dos y hasta tres meses desde la comunicación de la firmeza, que suelen prolongarse varias semanas más en la práctica, p.e.). Amén de su falta de justificación objetiva, la doctrina científica resalta con buenas razones la disparidad de trato con respecto al régimen contemplado en la legislación procesal civil y laboral ${ }^{24}$;

- la inobservancia del despacho automático de ejecución; y, por último,

- la exención de la imposición de costas en esta fase ${ }^{25}$.

En cuarto lugar, numerosos autores subrayan el escaso interés de Jueces y Tribunales hacia la fase de ejecución de sentencia consecuente con aquélla ${ }^{26}$. Así, J. $M^{a}$. Baño León estima que "para los jueces la ejecución de las sentencias contra la Administración suele concebirse como un estorbo, de suerte que lo usual es que rara vez el juez dirija la ejecución de la sentencia, permitiendo dilaciones indebidas e injustificadas de todo tipo en la ejecución”"27.

A ello se une el comportamiento de la Administración litigante y sus representantes procesales. J.A. Santamaría Pastor señala justamente que se trata de "un mandante totalmente desinteresado del litigio durante todo su desarrollo, pero que, ante un fallo contrario a sus intereses, no hace ningún esfuerzo por ocultar sus peores modos y por hacer uso de todo su poder para incumplirlo, si está en su mano. La ejecución de las sentencias se materializa en muchos casos, pues, en un trabajo desagradable; en un ingrato cuerpo a cuerpo con unos interlocutores, displicentes y poderosos, que invariablemente consideran el fallo judicial como un disparate que merece todo tipo de resistencias, hasta el límite de la acción penal; en una fase procesal en la que los poderes del juez no se encuentran excesivamente precisados, de modo que ha de moverse entre el temor al exceso y la sensación de una inconveniente prudencia, que sólo favorece los desplantes y los desafíos de muchas Administraciones, y las agrias

24 Vid. PÉREZ ALONSO, J. (2015: 8).

25 Vid., entre otros, SORIANO GARCÍA, J.E., El Poder, la Administración y los jueces (a propósito de los nombramientos por el Consejo General del Poder Fudicial, Iustel, Madrid, 2012, págs. 27 y 28. Hay que retener, entre otros privilegios administrativos; o PÉREZ ALONSO, J. (2015: 3).

26 La Magistrada C. Picó Lorenzo reconoce que "tal innegable realidad (la sujeción del principio de seguridad jurídica-tutela judicial efectiva al de legalidad presupuestaria) evidencia que las manifestaciones referidas a la débil actuación jurisdiccional contra la Administración para el cumplimiento de las obligaciones fijadas en sentencia, con ser sustancialmente ciertas, no solventan la insuficiencia jurídico-material para llevar a efecto el mandato constitucional en la forma debida. Todo ello, claro está, sin negar la ausencia de un auténtico control "de oficio" de las ejecuciones por los órganos jurisdiccionales que veden eventuales "cambalaches" entre las partes para eludir el cumplimiento del fallo" (vid. PICÓ LORENZO, C., "La ejecución de sentencias", en la obra colectiva dirigida por ella misma y titulada La nueva Ley de la furisdicción contencioso-administrativa, CGPJ, Madrid, 1999, págs. 465-530, en concreto pág. 474).

27 Vid. BAÑO LEÓN J. Ma . (2016: 86). 
quejas de los recurrentes. En tal situación, el desinterés de algunos órganos judiciales hacia los incidentes de ejecución es no sólo comprensible, sino incluso justificable"28.

En quinto lugar, en conexión con lo anterior, todos los autores denuncian de forma contundente los abusos de las Administraciones litigantes que, so pretexto de un interés público al que dicen servir, con demasiada frecuencia emplean cualesquiera argucias para obstaculizar el cumplimiento de los fallos aprovechando los resquicios y carencias legales (por ejemplo, mediante la pura y simple pasividad o, por el contrario, el ejercicio de sus potestades normativas, etc... $)^{29}$. Resulta lapidaria la valoración de J. González Pérez: "hoy es una vergüenza la pasividad de los Poderes del Estado ante el desprecio de los fallos de los Tribunales de que hacen (gala) las autoridades de algunas Comunidades Autónomas" ${ }^{30}$.

En sexto lugar, también es objeto de crítica severa la resistencia de los Jueces y Tribunales a enjuiciar en sede de ejecución, con fundamento en lo dispuesto en el artículo 103.4 LJCA, los actos y disposiciones dictados por la Administración para dar cumplimiento a sus sentencias y su preferencia en su lugar por proponer a los ejecutantes la interposición de un nuevo recurso contra los mismos en contra de lo establecido por aquélla y más aún, por el artículo 24 de la Constitución, que garantiza a todas las personas el derecho fundamental a una tutela judicial que sea efectiva $^{31}$.

Semejante actuación suscita un dilema muy serio a los abogados que sintetiza el Profesor Fernández Rodríguez del modo que sigue: "seguir la invitación del Tribunal e interponer un nuevo recurso supone renunciar a la victoria que uno creía haber obtenido y volver a empezar desde el principio, lo que resulta muy duro en cualquier caso. Pero, si uno opta por no seguir la invitación del Tribunal y continuar hasta el final, recurso de casación incluido, por la vía abierta por el artículo 103.4 de la Ley, el panorama que se le ofrece no es mejor, ya que el recurso de casación ante el Tribunal Supremo tarda más tiempo en resolverse que un nuevo recurso contencioso-administrativo, amén de la incertidumbre y el coste que todo recurso de casación. ¿Qué

28 Vid. SANTAMARIA PASTOR, J.A. (2010: 1088 y 1089).

29 Desde hace décadas la doctrina científica se pronuncia categóricamente contra el incumplimiento habitual de las sentencias por parte de las Administraciones Públicas. Baste por todas las citas de FERNÁNDEZ RODRÍGUEZ, T.R. (1974: 151-178), PÉREZ ALONSO, J (2015: 40) o BAÑO LEÓN J. Ma. (2016: págs. 85-102).

30 Vid. Comentarios a la Ley de la furisdicción Contencioso-Administrativa (Ley 29/1998, de 13 de julio), Civitas Thomson Reuters, Madrid, $7^{\mathrm{a}}$ ed., 2013, pág. 103.

31 No menos importancia desde un punto de vista cualititativo reviste la práctica de la Administración condenada que consiste en considerar el acto de ejecución exigido por la Sentencia condenatoria como un acto administrativo más objeto de notificación a los interesados (pero no al Juez o Tribunal, pese al dispuesto por el artículo 103.3 LJCA), independiente de aquélla. Vid. al respecto, BAÑO LEÓN J. Mª (2016: 87 y ss.). 
hacer entonces? Lo más sensato parece no perder el plazo para interponer un nuevo recurso con el acto o disposición que la Administración puede dictar para cumplir la Sentencia, porque los Autos que rechazan los intentos de ejecución planteados al amparo del artículo 103.4 invitan sí a iniciar un nuevo proceso, pero cuando lo hacen, ya ha pasado con mucho el plazo de dos meses que para interponer un recurso otorga el artículo 46 de la Ley de la Jurisdiccional y la invitación nada dice de que ese plazo pueda reabrirse". Por eso "si no hay jueces dispuestos a aplicarlas (las Leyes) con decisión de nada valen las Leyes" (sic) ${ }^{32}$.

Afortunadamente hay fallos meritorios como la Sentencia dictada por el Tribunal Supremo el 27 de febrero de 2008 (recurso de casación no 3247/2006), que pone de manifiesto cómo se esfuerza en interpretar y aplicar de forma correcta la LJCA: no puede tenerse por ejecutado un fallo, que es inequívoco, por unos Autos del Tribunal Superior de Justicia de Madrid que en rigor lo contradicen, máxime a la vista de la pasividad de la Administración condenada durante casi dieciocho años, porque

"la publicación del nuevo Real Decreto casi dieciocho años después de la promulgación del de 1987 sin que la Disposición Transitoria Primera de éste se hubiera desarrollado, y cuatro años y medio después de que una Sentencia firme hubiera dispuesto su desenvolvimiento, no satisface el derecho reconocido al recurrente por el Tribunal y, en consecuencia, vulnera el derecho a la tutela judicial efectiva que consagra el art. 24 de la Constitución, derecho que comprende ineludiblemente el de hacer ejecutar lo juzgado, y que en este caso no ha sido satisfecho" (sic).

En consecuencia, a la vista de las posibilidades legales y de la claridad del fallo de 14 de octubre de $2000^{33}$, que contiene una condena a la Administración pendiente

32 Vid. FERNÁNDEZ RODRÍGUEZ, T. R., "El artículo 103.4 LJ no les gusta a los Jueces", en SÁNCHEZ BLANCO, A., DOMÍNGUEZ-BERRUETA DE JUAN, M. y RIVERO YSERN, J.L. (coordinadores), El nuevo Derecho Administrativo. Libro homenaje al Profesor Doctor Enrique Rivero $Y_{\text {sern, Ratio Legis y }}$ Universidad de Salamanca, Salamanca, 2011, págs. 139-146, en particular página 146; y, en esta misma línea, p.e., HUERGO LORA, A., "La permanencia de un viejo problema: la reiteración de los actos administrativos anulados como forma de incumplimiento indirecto de las sentencias, con especial referencia a los efectos de los recursos de casación en interés de Ley", Revista de Administración Pública (2001) 156, págs. 283-306; BOCANEGRA SIERRA, R., "La anulación en incidente de ejecución de sentencia de decisiones administrativas que infringen lo ejecutoriado", en GARCÍA DE ENTERRÍA, E. y ALONSO GARCÍA, R., (coordinadores), Administración y Justicia. Un análisis jurisprudencial. Liber amicorum Tomás-Ramón Fernández, volumen I. España, Civitas Thomson Reuters, Madrid, 1ª ed., 2012, págs. 789-801; y DE MIGUEL PAJUELO, F., "Capitulo 7. La Ejecución de las Sentencias", en PALOMAR OLMEDA, A., (director), Tratado de la Furisdicción Contencioso-Administrativa, Tomo II. Recursos, Ejecución de Sentencias y Disposiciones Comunes, Aranzadi Thomson Reuters, Pamplona, 2a ed., 2012, págs. 795 y ss., en especial págs. 820-822.

33 El Tribunal Supremo declara "el derecho del demandante a que por el órgano competente se dé cumplimiento al mandato contenido en la Disposición Transitoria Primera del Real Decreto 992/1987, 
de ejecución ineludible, el Tribunal Supremo estima que en puridad su recto cumplimiento del fallo exige que ésta

"a través del órgano competente una vez que la Sentencia dio por acreditados en el recurrente los requisitos objetivos exigidos por la Disposición Transitoria Primera deberá requerir al Sr. Juan Antonio para que, de acuerdo con la misma, presente o bien un trabajo de investigación sobre la especialidad Obstétrico-Ginecológica (Matronas) que será evaluado del modo que la Administración disponga, o supere las pruebas que la Administración convoque y que versarán sobre los programas de formación de la Especialidad respectiva. Para cumplir lo expuesto se establece por la Sala un plazo de seis meses a partir del momento en que la Sentencia le sea notificada a la Administración" (sic).

En séptimo lugar, debe notarse que ciertas soluciones jurisprudenciales que no se compadecen de respaldo claro e inequívoco en el derecho fundamental a la tutela judicial efectiva y en la legislación ordinaria. Es el caso, por ejemplo, de la autoatribución de una potestad jurisdiccional de suspensión de la ejecución de las sentencias en el supuesto de su impugnación en vía de amparo constitucional, siempre que de ella puedan derivarse daños y perjuicios irreversibles en caso de otorgamiento de dicho amparo, y únicamente durante el plazo que medie entre su interposición y el pronunciamiento del Tribunal Constitucional sobre la adopción de aquella medida cautelar de suspensión (así, Sentencia del Tribunal Supremo de 9 de diciembre de 2014 [recurso de casación no 5270/2011] $)^{34}$.

En octavo lugar, deben ponerse de relieve las dificultades de diverso tipo suscitadas por los casos de imposibilidad legal o material de ejecución de sentencias contemplados en el artículo 105.2 LJCA, a las que se suman en sectores paradigmáticos como el urbanismo ${ }^{35}$ ciertos comportamientos de los particulares dirigidos a forzar

de 13 de julio, realizando el desarrollo reglamentario establecido en la misma, condenando a la Administración a estar y pasar por esta declaración y a adoptar las medidas necesarias para llevarla a efecto".

34 Vid. al respecto, EZQUERRA HUERVA, A., "Ejecución de sentencias contencioso-administrativas y adopción de medidas cautelares. En particular, la suspensión de la ejecución de sentencias por el Tribunal de instancia en caso de interposición de recurso de amparo", Revista de Administración Pública (2005) 197, págs. 271-304.

35 Vid. acerca de la ejecución de sentencias en materia de urbanismo, en los últimos años se han sucedido un buen número de publicaciones interesantes. Valga la cita de las siguientes por orden cronológico, pero sin ánimo de exhaustividad:

-MENÉNDEZ PÉREZ, S., "De nuevo sobre la ejecución de sentencias urbanísticas: la salvaguarda de los intereses de los adquirentes de las viviendas de un edificio ilegalmente construido (a propósito de un supuesto de aplicación del art. 73 del TRLS de 1976. Construcción no adaptada al ambiente en que se sitúa. STS de 4 de mayo de 2004)", Revista Aranzadi de Urbanismo y Edificación (2004) 10, págs. 119-125; 
la prevalencia de los hechos consumados en los supuestos de anulación judicial de instrumentos de planeamiento o de licencias de obras con posterioridad a la terminación (o casi) de las obras de urbanización e, incluso, de la construcción de las viviendas y hasta después de la conclusión de una o varias transmisiones de las mismas

-SÁMANO BUENO, P., "La ejecución de sentencias en materia de urbanismo: repaso del estado de las cosas y alguna propuesta", Revista de Derecho Urbanístico y Medio Ambiente (2007) 238, págs. 149-216;

- RAZQUIN LIZARRAGA, J.A., "Tutela judicial efectiva e imposibilidad legal de ejecución de sentencias en materia de urbanismo", Revista Aranzadi Doctrinal (2009) 3, págs. 85-99;

- REVUELTA PÉREZ, I. y NARBÓN LAINEZ, E., "Ejecución de sentencias en materia urbanística, demolición y terceros adquirentes de buena fe. El caso de la anulación de licencias", Revista Crítica de Derecho Inmobiliario (2010) 720, págs.1595-1646;

-REVUELTA PÉREZ, I., "Demoliciones urbanísticas y buena fe dominical", Revista Aranzadi de Urbanismo y Edificación (2011) 23, págs. 97-111;

-GUILARTE GUTIÉRREZ, V., Legalidad urbanística, demolición y terceros adquirentes de buena fe (Luces y sombras del registro español y del principio de fe pública: la incidencia de las sentencias de las salas $1^{a}$ y $3^{a}$ del Tribunal Supremo sobre su funcionalidad), Lex Nova, Valladolid, 2011;

- GUILARTE GUTIÉRREZ, V., "Crítica civil a las demoliciones derivadas de la anulación de licencias: la aplicación del art. 34 L.H.", Revista Aranzadi de Urbanismo y Edificación (2012) 26, págs. 21-49;

- REVUELTA PÉREZ, I, "La ponderación del derecho de propiedad en la ejecución de sentencias urbanísticas. Crítica a la doctrina de la demolición del Tribunal Supremo", en GARCíA DE ENTERRÍA, E. y ALONSO GARCÍA, R. (coordinadores), Administración y Fusticia. Un análisis jurisprudencial. Liber amicorum Tomás-Ramón Fernández, volumen I. España, Civitas Thomson Reuters, Madrid, 1ª ed., 2012, págs. 20352061 ;

- MARTÍN REBOLLO, L., "Ejecución de sentencias de derribo y técnicas obstruccionistas (A propósito de la STC 92/2013, de 22 abril)", Revista Aranzadi de Urbanismo y Edificación (2013) 28, págs. 19-40;

- FERNÁNDEZ RODRÍGUEZ, T.R., "Proceso contencioso-administrativo y urbanismo: semejanzas y diferencias de los casos francés y español", Revista Aranzadi de Urbanismo y Edificación (2013) 29, págs. 77-95;

- RUIZ ARNAIZ, G., "Los terceros de buena fe en la ejecución de sentencias (a propósito de la STS de 16 de abril de 2013)", Revista Aranzadi de Urbanismo y Edificación (2013) 29, págs. 15-37;

- RUIZ BURSÓN, J., "El tercero hipotecario frente a los deberes urbanísticos: comentario a la Sentencia del Tribunal Supremo de 20 de marzo de 2013", Revista Aranzadi de Urbanismo y Edificación (2014) 30, págs. 339-355;

- ALONSO IBÁÑEZ, Ma . R., "La imposibilidad de ejecución de sentencias de demolición de edificaciones: medidas legales", en SORIANO GARCÍA, J.E. (director), Por el Derecho y la Libertad. Libro Homenaje al Profesor Juan Alfonso Santamaría Pastor, Iustel, Madrid, 2014, volumen I, pp. 963-994;

- GONZÁLEZ BOTIJA, F. y RUIZ LÓPEZ, M.A. "La ejecución de sentencias de derribo y los terceros de buena fe (a propósito del nuevo artículo 108.3 de la Ley de la Jurisdicción Contencioso-Administrativa)", Revista Aranzadi de Urbanismo y Edificación (2015) 35, págs. 23-45;

- BERMÚDEZ FERNÁNDEZ, A. L. "La demolición urbanística a la luz del artículo 108.3 de la LJCA. Certezas e interrogantes", Revista Aranzadi de Urbanismo y Edificación (2017) 39, págs. 43-71;

- FERNÁNDEZ RODRÍGUEZ, T.R., "El contencioso urbanístico y su necesaria reforma”, Revista de Administración Pública (2017) 203, págs. 137-162;

- PECES MORATE, J.E., "La justicia en el urbanismo y el medio ambiente: ¿se cumplen las sentencias?", Revista de Derecho Urbanístico y Medio Ambiente (2017) 311, págs. 323-342; y

- ALONSO MAS, Ma J. y REVUELTA PÉREZ, I, Buena fe contra demolición urbanística. Cuestiones sustantivas y procesales, Thomson Reuters Aranzadi, Pamplona, monografía ligada a la Revista Aranzadi de urbanismo y edificación, $1^{\mathrm{a}}$ ed., 2018. 
a terceras personas y otros muchos negocios inter privatos (contratación de créditos, constitución de hipotecas, etc. $)^{36}$.

Ello no empece para reconocer que en no pocas ocasiones esas dificultades (las legales, en especial) son más aparentes que reales, sobre todo cuando concurren razones sólidas de interés público que permiten evitar la demolición de las obras amparadas en licencias o autorizaciones anuladas por sentencia firme ${ }^{37}$, validándolas mediante la aprobación ulterior de un instrumento de planeamiento que pretenda tan sólo atender aquéllas de forma racional, pero no convertir lo ilegal en legal e incumplirla ${ }^{38}$.

Con todo, es palpable la tensión entre el principio de legalidad por un lado, que exige la demolición de lo construido, sobrevenidamente ilegal como consecuencia de la anulación de la correspondiente licencia mediante Sentencia firme, y los de seguridad jurídica, confianza legítima y buena fe registral por otro, que exigen la tutela de los terceros adquirentes de buena fe con fundamento en lo dispuesto en el artículo 34 de la Ley Hipotecaria. Pero lo cierto es que el Tribunal Supremo se ha venido inclinando mayoritariamente a favor del principio de legalidad ${ }^{39}$.

36 Vid. FERNÁNDEZ RODRÍGUEZ, T.R. (2017: 141); y RUIZ LÓPEZ, M. A., "La tutela cautelar no ampara ilegalidades urbanísticas: reflexiones acerca de las soluciones de normalización (a propósito de la STS de 17 de mayo de 2013, edificio "Banana Beach" de Marbella)", Revista de Urbanismo y Edificación (2013) 29, págs. 101-119.

37 Vid. los ejemplos expuestos por FERNÁNDEZ RODRÍGUEZ, T.R. relativos al reconocimiento de la existencia de sendas causas de imposibilidad material de ejecución de fallos anulatorios de

- un expediente expropiatorio que habría impedido la prestación del servicio público de suministro domiciliario de agua potable (Auto del Tribunal Supremo de 19 de enero de 1994),

- las licencias para la instalación y construcción de una planta de cogeneración (Sentencias del Tribunal Supremo de 23 de junio de 2009 y 25 de enero de 2011),

- los acuerdos de delimitación de una unidad de actuación urbanística y de elección del sistema de expropiación (Sentencia del Tribunal Supremo de 9 de febrero de 2009) (vid. 2013: 83 y 84).

38 Vid. al respecto, FERNÁNDEZ VALVERDE, R., "La ejecución de las sentencias en el ámbito urbanístico (Parte primera)", Revista Aranzadi de Urbanismo y Edificación (2009a) 20, págs. 15-35; del mismo autor, "La ejecución de las sentencias en el ámbito urbanístico (Parte segunda)", Revista Aranzadi de Urbanismo y Edificación (2009b) 21, págs. 15-47. Esta es justamente la tesis defendida con sólidos argumentos por GÓMEZ-FERRER RINCÓN, R. (vid. La imposibilidad de ejecución de sentencias en el proceso contencioso-administrativo, Civitas Thomson, Madrid, 2008).

39 Vid. una síntesis de la jurisprudencia contencioso-administrativa acerca la afectación de los terceros de buena fe por sentencias anulatorias de licencias urbanísticas que ordenan la demolición de lo construido en RUIZ ARNAIZ, G (2013: 20 y ss.). Por otra parte, es de indicar que la doctrina científica es prácticamente unánime al calificar la postura del Tribunal Supremo, tildándola de "tradicionalmente insensible a esta situación, al entender que el que los propietarios tuviesen la condición de terceros adquirentes de buena fe carecía de trascendencia a los efectos de impedir la ejecución de una sentencia que impusiese la demolición del inmueble de su propiedad por no ajustarse a la legalidad urbanística, pues la fe pública registral y el acceso de sus derechos dominicales al Registro de la Propiedad no subsanaba el incumplimiento del ordenamiento urbanístico" (vid. GONZÁLEZ BOTIJA, F. y RUIZ LÓPEZ, M.A. (2015: 25). 
Ello explica la búsqueda de soluciones bienintencionadas de carácter alternativo, en un principio allí donde la tensión social y jurídica es más intensa. En este contexto se inserta, p.e, la reforma parcial de la Ley $2 / 2001$, de 25 de junio, de Ordenación Territorial y Régimen Urbanístico del Suelo de Cantabria, por medio de la Ley 2/2011, de 4 abril, con el fin de condicionar la demolición de lo construido a la previa terminación del expediente de responsabilidad patrimonial, la eventual fijación de una indemnización y su puesta a disposición de la víctima (D.A. $6^{\text {a)}}$.

No obstante, el Tribunal Constitucional acaba frustrándola por entender que dicho condicionamiento por ley autonómica de la eficacia de la ejecución de las sentencias firmes invade competencias estatales en materia de legislación procesal, motivo por el que la anula (STC 92/2013, de 22 de abril $)^{40}$. Lo hace no sin advertir, en línea con la jurisprudencia contencioso-administrativa contenida en las Sentencias del Tribunal Supremo de 12 de febrero de 2013, 13 de marzo de 2013 y 30 de abril de $2013^{41}$, que ello no prejuzga la actuación de Jueces y Tribunales, pues

"qué duda cabe de que los órganos judiciales deberán ponderar la totalidad de los intereses en conflicto a la hora de hacer ejecutar sus resoluciones y que no cabe descartar que tal ponderación pudiera llevar al órgano judicial a acomodar el ritmo de la ejecución material de las demoliciones que hayan de tener lugar a las circunstancias concretas de cada caso" (FJ 6, in fine).

La Ley Orgánica 7/2015, de 21 de julio, pretende con el nuevo artículo 108.3 LJCA retomar en buena medida el planteamiento de la Ley cántabra 2/2011 declarada inconstitucional, a la vista de la argumentación sostenida por el Tribunal Constitucional en su Sentencia 92/2013. No en balde dicho precepto prescribe que el Juez o Tribunal ${ }^{42}$ que declare ilegal la construcción de un inmueble y ordene motivadamente su demolición y la reposición a su estado originario de la realidad física alterada "exigirá, como condición previa a la demolición, y salvo que una situación de peligro inminente lo impidiera, la prestación de garantías suficientes para responder del pago de las indemnizaciones debidas a terceros de buena fe". Significa, de acuerdo con la doctrina jurisprudencial, que, en contra de lo defendido por las Administraciones condenadas mediante Sentencias firmes,

"la exigencia de la prestación de garantías suficientes para responder del pago de las indemnizaciones debidas a terceros de buena fe, a la que se refiere el precepto como condición previa a la demolición de un inmueble ordenada

40 Me remito en este punto al riguroso e incisivo estudio de MARTÍN REBOLLO, L. (2013: 19-40).

41 Vid. infra.

${ }^{42}$ Vid. acerca del contenido y alcance de esta novedad legislativa, GONZÁLEZ BOTIJA, F. y RUIZ LÓPEZ, M.A. (2015: 23-45); y BERMÚDEZ FERNÁNDEZ, A. L. (2017: 43-71); entre otros. 
por un Juez o Tribunal, no precisa la tramitación de un procedimiento contradictorio ni requiere que tales indemnizaciones hayan sido fijadas como debidas en un procedimiento de responsabilidad patrimonial o en un incidente de ejecución de sentencia en el que se declare y reconozca el derecho del tercero y determine la cantidad líquida que resulte exigible por el mismo, sino que se configura como un trámite integrado en la ejecución de sentencia, que consiste en la adopción por el órgano jurisdiccional de las medidas de aseguramiento que resulten suficientes para responder del pago de las indemnizaciones que puedan reconocerse a terceros de buena fe al margen del proceso, medidas de aseguramiento que han de ser valoradas, en su existencia y alcance, por el órgano judicial atendiendo a los datos y elementos de juicio de que disponga y pueda recabar en el procedimiento, resolviéndose las controversias que puedan surgir al respecto, en el correspondiente incidente de ejecución de sentencia, como dispone el art. 109.1 de la Ley Jurisdiccional" (Sentencias del Tribunal Supremo de 21 de marzo de 2018 [recursos de casación n ${ }^{\circ}$ 138/2017 y n 141/2017]) $)^{43}$,

43 Existe ya un cuerpo de doctrina, a propósito por cierto de prácticamente los mismos litigantes (la Asociación para la Defensa de los Recursos Naturales de Cantabria, más conocida por su acrónimo ARCA, por un lado, y la Comunidad Autónoma de Cantabria y varios Ayuntamientos -Piélagos, Argoños- por otro), integrado por las Sentencias del Tribunal Supremo de Sentencias de 25 de mayo de 2018 (recurso de casación $n^{\circ} 325 / 2016$ ), 1 de junio de 2018 (recurso de casación n $n^{\circ}$ 571/2017), 18 de junio de 2018 (recurso de casación n 1093/2017), 28 de junio 2018 (recurso de casación n ${ }^{\circ}$ 1/2016), 2 de julio de 2018 (recurso de casación n ${ }^{\circ}$ 1749/2017) y 11 de julio de 2018 (recurso de casación n ${ }^{\circ}$ 140/2017).

Además, en su Sentencia de 1 de junio de 2018 (recurso de casación n 571/2017), el Tribunal Supremo ratifica lo dispuesto en su fallo de 21 de noviembre de 2017, desmintiendo que el citado artículo 108.3 LJGA pueda ser considerado una causa de inejecución:

"de forma particular, del tenor literal del contenido de los últimos fundamentos de dicha resolución (FJ $12 .^{\circ}$ a $14 .^{\circ}$ ), resulta claro así que, conforme a nuestra doctrina jurisprudencial: 1. ${ }^{\circ}$ el artículo 108.3 LJCA no impide la ejecución de sentencias; $2 .^{\circ}$ tampoco constituye causa alguna de inejecución de tales resoluciones, al amparo del artículo 105.2 LJCA; y $3 .^{\circ}$ no vulnera ello el artículo 24 de la Constitución (antes bien, precisamente, pudiera suceder esto así de prosperar el planteamiento de parte, esto es, de entenderse que el artículo 108.3 LJCA impide la ejecución de sentencias)".

Ya en su Sentencia de 21 de septiembre de 2017 (recurso de casación n ${ }^{\circ}$ 477/2016) el Tribunal Supremo había declarado con toda nitidez que

"tanto desde una perspectiva temporal como sistemática permite afirmar que el legislador no ha pretendido dispensar a los propietarios y a la administración de una medida genérica e indiscriminada de suspensión o paralización temporal de las ejecuciones de las sentencias de demolición de inmuebles, sino de dotar al juez, una vez acreditada la necesidad, adecuación y proporcionalidad de la demolición, de determinados poderes en orden a que dicha demolición no haya de causar efectos irreparables en los terceros adquirentes de buena fe. Esto es, mientras el art. 105 lo que prevé son supuestos de inejecución de sentencias por causas legales o materiales, el art. 108.3 se sitúa en un momento posterior del proceso de ejecución, en cuanto se incluye en un precepto que recoge los poderes del juez para que la ejecución se lleve a efecto, 
de forma que

"se asegura que, al margen de la efectividad y materialización del derecho a la regularización urbanística declarado en la sentencia que se ejecuta, resulte igualmente efectivo el reconocimiento del derecho de terceros a la correspondiente indemnización, que aun no habiendo sido objeto del proceso, pueda ser reconocido en otro distinto y legalmente previsto al efecto" (Sentencias del Tribunal Supremo de 21 de marzo de 2018 [recursos de casación no 138/2017 y n 141/2017]).

con lo cual se convierte en una fase más de la ejecución, pero nunca en un impedimento, ni siquiera temporal para la ejecución de la sentencia.

Consecuentemente se ha de entender que lo que hace la norma no es regular un obstáculo a la ejecución, sino añadir un deber de hacer en la ejecución de estos fallos. Al deber de demoler, se une el de garantizar los perjuicios que puedan derivarse para los adquirentes de buena fe. En caso de no hacerlo, el juez debe ocuparse de que así sea, adoptando medidas de coerción y exigiendo responsabilidades de todo tipo, hasta que se haya constituido la garantía, voluntariamente o de forma forzosa, esto es el juez deberá, dentro del mismo proceso de ejecución de la sentencia de demolición, ir resolviendo paralelamente sobre estas cuestiones, teniendo como objetivo final conseguir la restauración del orden jurídico alterado, finalidad conforme al interés público que el proceso demanda, sin perjuicio de la tutela de los intereses privados que puedan verse concernidos.

En definitiva, el legislador, junto con la finalidad de preservación del interés público que protege la ejecución de sentencias urbanísticas en cuanto instrumento dirigido al restablecimiento de la realidad física alterada, ha tratado de introducir la defensa y protección por parte del órgano judicial de los intereses privados de aquellos que habiendo adquirido de buena fe, pueden resultar perjudicados por tal ejecución, si bien, consideramos, que dicha protección no puede alzarse ni considerarse preeminente al interés público que en el proceso se trata de proteger y restaurar".

Justamente esta argumentación conduce al Tribunal Supremo a entender que

"De todo lo expuesto se deduce la configuración de un trámite integrado en el procedimiento de ejecución de la sentencia, que no supone un obstáculo a la ejecución sino la acomodación de la misma a las circunstancias propias de este tipo de procesos desde una doble perspectiva, atendiendo, por un lado, a la efectividad del derecho y los intereses reconocidos en la sentencia y, por otro, a la garantía de aquellos otros intereses económicos o indemnizaciones que puedan reconocerse a terceros de buena fe al margen del proceso, y que consiste en la adopción por el órgano jurisdiccional de las medidas de aseguramiento que resulten suficientes para responder del pago de las mismas, medidas de aseguramiento que, como sucede en la generalidad de los supuestos en que se establecen por la ley en previsión de posibles responsabilidades, han de ser valoradas, en su existencia y alcance, por el órgano judicial competente para ello, atendiendo a los datos y elementos de juicio de que disponga y pueda recabar en el procedimiento, resolviéndose las controversias que puedan surgir al respecto, en el correspondiente incidente de ejecución de sentencia, como dispone el art. 109.1 de la Ley Jurisdiccional" (Sentencias del Tribunal Supremo de 21 de marzo de 2018 [recursos de casación no 138/2017 y n 141/2017]). 
Así y todo, la fórmula introducida por la citada Ley Orgánica 7/2015 ni oculta, ni menos aún resuelve los complejos problemas que genera la imposibilidad legal de ejecución de sentencias, entendida rectamente como una vía de solución para supuestos excepcionales so pena de su desnaturalización.

Los motivos expuestos revelan, en definitiva, que para la mayoría de la doctrina científica y la abogacía "la situación no es que se haya estancado, sino que ha ido claramente a peor desde la perspectiva del ciudadano", convertido en un "auténtico vía crucis" ${ }^{44}$. Así, a juicio del Profesor Fernández Rodríguez, "por desgracia, nada ha cambiado realmente y (que) ni la Constitución, ni la Ley, ni la jurisprudencia del Tribunal Constitucional y del Tribunal Supremo han conseguido desarraigar la prepotencia de los administradores. Y, lo que todavía es peor, tampoco han logrado incrementar la fortaleza de muchos jueces, que, lejos de poner coto a esa prepotencia, prefieren mirar para otro lado con el más mínimo pretexto" ${ }^{\text {. }}$.

\section{PERSPEGTIVAS DE FUTURO}

Están lejos de cumplirse las previsiones formuladas por la doctrina científica ${ }^{46}$. Qué duda cabe que ninguna previsión, por muy objetiva y racional que pretenda ser, puede confirmarse ante una conducta contumazmente arbitraria como, por ejemplo, la exhibida por la Generalidad de Cataluña, en materia de política lingüística ${ }^{47}$.

${ }^{44}$ Vid. PÉREZ ALONSO, J. (2015: 1).

45 Vid. FERNÁNDEZ RODRÍGUEZ, T. R. (2011: 139). Más adelante, afirma, en coincidencia con el parecer de otros autores, como el Profesor Santamaría Pastor, que "el artículo 103.4 de la vigente Ley Jurisdiccional no tiene, ciertamente, la mejor redacción posible, pero, como ha podido verse, no es dificil de superar el desconcierto que produce en un primer momento su inciso final. El problema, repito, no está ahí. Sigue estando donde siempre estuvo: en la prepotencia y en el desahogo de los administradores y en el desfallecimiento de los Jueces, que lamentablemente terminan por ceder cuando el forcejeo con aquéllos se prolonga" (ibidem, pág. 143).

$46 \quad$ En la $6^{\mathrm{a}}$ ed. del volumen II, correspondiente al $25^{\circ}$ aniversario de su publicación, los Profesores García de Enterría y Fernández afirmaban que "el sistema arbitrado por la LJ puede estimarse como uno de sus mayores aciertos y es de esperar que corrija definitivamente la situación pasada" (vid. GARCÍA DE ENTERRÍA, E. y FERNÁNDEZ RODRÍGUEZ, T.R., Curso de Derecho Administrativo, Civitas, Madrid, volumen II, 6 a ed., 1999, págs. 640 y 641).

47 Me remito a este respecto al concienzudo trabajo del Profesor Betancor, que concluye con una reflexión compartida por muchos otros autores: "el derecho sólo será eficaz, una vez más, si el juez, comprensivo de su función y de sus obligaciones, tiene la voluntad, pero también los medios, de vencer a la arbitrariedad. Nos encontramos con el nuevo eterno reto del Estado de derecho: doblegar, con la ley, a la arbitrariedad que atropella no sólo al derecho fundamental a la tutela judicial efectiva, sino también al derecho que dicha tutela ampara, el derecho a que la enseñanza se imparta en las dos lenguas vehiculares en la proporción razonable, aquélla que la propia realidad ha ido estableciendo" [vid. BETANCOR, A. "Inejecución de sentencias que condenan a la Administración a desplegar una actuación dirigida a la realización de un derecho subjetivo. El caso de la reintroducción del castellano como lengua vehicular en la enseñanza catalana", Revista de Administración Pública (2016) 201, págs. 145-177, en especial, pág. 177]. 
Dicho esto, ¿qué sería preciso para mejorar un estado de cosas tan insatisfactorio? En primer lugar, la mayoría de los autores insisten en la necesidad de un mayor compromiso de los Tribunales, que pasa indefectiblemente por el abandono del rigorismo formal prevalente en el curso de los últimos años ${ }^{48}$. En este sentido, se antoja indispensable "un cambio de la mentalidad tradicional de los jueces, un tránsito desde la actitud propia de meros censores, ahora radicales, que se desentienden pura y simplemente del resultado de su censura por considerar que no es cosa suya, en una aplicación ciega del fi at iustitia et pereat mundus a la de colaboradores en una tarea común de regularización de lo que razonablemente pueda considerarse subsanable, de limitación de la contaminación de los actos posteriores al declarado nulo y de las subsiguientes nulidades en cadena e, incluso, de guía capaz de evitar ulteriores tropiezos" $" 49$.

Lo expuesto no quita para reconocer que en algunos ámbitos se han producido avances elogiables. Particular interés reviste la interpretación finalista, y por ello mismo más flexible, del artículo 105.2 LJGA que postula el Tribunal Supremo. En virtud de dicha interpretación, el Juez o Tribunal competente puede pronunciarse al resolver el incidente de ejecución no sólo sobre la concurrencia o no de una causa de imposibilidad legal o material de ejecución de la sentencia en sus propios términos, sino además, en caso afirmativo, sobre las medidas a adoptar (previsiblemente a instancia del Ayuntamiento condenado, pero también incluso de oficio) como forma alternativa de su cumplimiento que garanticen dentro de lo posible la mayor efectividad de la ejecutoria y la restauración de la legalidad e, incluso, sobre la procedencia (previa prueba de la existencia de daños y perjuicios, algo imposible tratándose de

48 Vid., p.e., FERNÁNDEZ TORRES, J.R., "Arbitrariedad y discrecionalidad, dos décadas después", en GARCÍA DE ENTERRÍA, E. y ALONSO GARCÍA, R. (directores), "Administración y Justicia. Un análisis jurisprudencial. Libro homenaje a T. R. Fernández", Civitas Thomson Reuters, Madrid, 1 a ed., 2012, págs. 1109-1144; del mismo autor, “¿Formalismo exacerbado o simple defensa de la legalidad?”, Revista Aranzadi de Urbanismo y Edificación (2015) 33, págs. 183-199; y "La paradoja de la insuficiencia de recursos hídricos hunde el Plan General de Santander. A propósito de la STS de 8 de noviembre de 2016 (RC 2682/2015)", Revista de Administración Pública (2017) 203, págs. 165-183; además, en un plano más general, GARCÍA LUENGO, J., "Las infracciones formales como causa de invalidez del acto administrativo", Iustel, Madrid, 2016.

A juicio del Profesor Fernández Rodríguez, "se ha olvidado, se está olvidando sistemáticamente en estos últimos años, que, como dijo la vieja Sentencia de 29 de Enero de 1915, ¡hace un siglo, por lo tanto!, la apreciación de si un vicio de forma o de procedimiento entraña nulidad «depende de la importancia que revista, de la derivaciones que motive, de la situación o posición de los interesados en el expediente y, en fin, de cuantas circunstancias concurran, que deberán apreciarse en su verdadera significación y alcance para invalidar las consecuencias de los actos o para mantenerlos»... hay que evitar también el rigor y el garantismo excesivos, cuyos resultados no son mucho mejores. Pasarse es tan malo como no llegar y aquí y ahora nos hemos pasado, nos estamos pasando" (vid. 2013: 92; más recientemente, del mismo autor, 2017: 146 y ss.).

49 Vid. FERNÁNDEZ RODRÍGUEZ, T.R. (2017: 158). 
recursos abusivos o malintencionados ${ }^{50}$ ) y el importe de la indemnización por la parte en la que no sea posible el cumplimiento pleno de aquélla ${ }^{51}$. Semejante doctrina jurisprudencial posibilita la subsanación de los vicios formales o de procedimiento determinantes de la anulación del instrumento de planeamiento, por razones de eficacia ${ }^{52}$.

En segundo lugar, es inexcusable, por un lado, romper la inercia general de pasividad e indiferencia de los legisladores y las Administraciones Públicas en este campo y, por otro, introducir cambios legales, siguiendo, por qué no, el ejemplo fran-

50 "Crapuleux", o sea, extorsivos y gangsteriles, según el Informe Labetoulle titulado « Construction et Droit au recours: pour un meilleur équilibre » de 25 de abril de 2013. Precisamente en su edición de fecha 10 de agosto de 2018 el diario Le Monde dio a conocer la fuerte ("lourde") condena penal a un sujeto que, sirviéndose de una falsa asociación dirigida supuestamente a promover un urbanismo responsable y ecológico, entre 2015 y 2017 había interpuesto más de 70 recursos contra actos de concesión de licencias de obras de grandes proyectos inmobiliarios (de oficinas, equipamientos comerciales y hoteles) en París, con los que chantajeaba a propietarios (incluidas empresas muy conocidas), promotores y profesionales del sector, ofreciendo su desistimiento a cambio de la entrega de importantes sumas de dinero, gracias a lo cual amasó más de 1,6 millones de euros. La condena por la comisión de los delitos de estafa, falsificación y blanqueo de capitales conlleva una multa de 100.000 euros y la confiscación del beneficio ilegal.

51 Esta es la tesis defendida desde un principio por el Magistrado FERNÁNDEZ VALVERDE, R. (2009b: 32) y acogida por el Tribunal Supremo ya en sus Sentencias de 12 de febrero de 2013, 13 de marzo de 2013 y 30 de abril de 2013. Para aquél, "se trata, sin duda, de una habilitación legal escasamente explorada en la práctica jurisdiccional y que, por su ubicación sistemática no debe de ser entendida como una habilitación, exclusivamente, establecida para proceder a la ejecución de la sentencia en los mismos términos del fallo (pues ese mandato ya se contiene en el artículo 104.1 de la LRJCA). Por el contrario, este inciso del artículo 105 lo que implica es una específica habilitación al Juez o Tribunal para que, en el marco del supuesto de imposibilidad que el precepto regula, el órgano jurisdiccional pueda adoptar - entendemos que incluso de oficio- cuantas medidas resulten necesarias para la ejecución de la sentencia, aunque fuere de una forma diferente a la contemplada en el fallo, y sin tener que recurrir, de forma irremisible y necesaria, al mecanismo expresamente previsto de la indemnización, que, si bien se observa, no cuenta con el carácter de obligatorio, por cuanto el legislador se cuida de establecerla «en su caso». A título de ejemplo bien pudieran -cual medida compensatoria o indemnizatoria de ámbito general-imponerse, como modificaciones obligatorias del planeamiento, algún tipo de determinaciones urbanísticas de carácter público o social, con las que tratar de compensar la anterior vulneración de las normas urbanísticas cuya eliminación no ha resultado posible por la concurrencia de la causa expresada; la participación o la colaboración material o económica de los causantes o responsables de la infracción o de los beneficiados por la misma -jurisdiccionalmente impuesta con este apoyo- podría resultar un adecuado mecanismo que socialmente paliare o rehabilitare la situación de hecho producida y de imposible alteración futura; instrumento éste que, por otra parte, tendría acogida tanto en el marco del esencial principio de equidistribución de beneficios y cargas, como en el del ámbito de la adecuada gestión urbanística”.

52 Como precisa el Profesor Fernández Rodríguez, "si no han sido satisfactoriamente justificadas en la documentación del plan impugnado determinadas decisiones, apórtese en el propio incidente de ejecución la justificación adicional que se considere necesaria; si se omitió un informe solicítese éste; si el estudio económico-financiero era insatisfactorio, otórguese un plazo para su corrección; si es precisa una segunda información pública sobre las «modificaciones sustanciales» introducidas, practíquese, etc. Todo antes de meterse en un callejón sin salida que conduce a una demolición que es en muchos casos social y políticamente imposible" (vid. 2013: 91). 
cés, del que tenemos aún hoy día tanto que aprender ${ }^{53}$ tanto en lo relativo a las reglas procesales como en lo concerniente a las reglas sustantivas que aminoren la complejidad y la desmedida conflictividad actual y alivien la presión que soportan los Jueces y Tribunales ${ }^{54}$ permitiéndoles examinar con el tiempo y el sosiego y la serenidad indispensables los asuntos de verdadera enjundia, cambios que por lo tanto han de afrontar tanto el legislador estatal como los legisladores autonómicos.

¿Cuáles son las modificaciones legales que pueden contribuir a una mejora sustancial de la operatividad y eficacia de la ejecución de las sentencias? Deben comprender, entre otras medidas legales,

1) la erradicación de la acción pública, a la vista de la extraordinaria amplitud de la legitimación activa con fundamento en el artículo $24 \mathrm{CE}$ y su interpretación jurisprudencial, pues tal como la experiencia evidencia una y otra vez, "más allá de estos límites no hay intereses dignos de protección, porque no pueden ser considerados tales en ningún caso los que mueven a los recurrentes abusivos" ${ }^{\$ 5}$. El Profesor Fernández Rodríguez afirma de forma categórica que "nadie tiene derecho a la anulación de una decisión por infracciones que no le afectan"

53 Este es justamente el empeño del Profesor Fernández Rodríguez, de forma acusada en los últimos cinco años, a través de sus trabajos arriba citados, "Proceso contencioso-administrativo y urbanismo: semejanzas y diferencias de los casos francés y español", por un lado, y "El contencioso urbanístico y su necesaria reforma", por otro.

54 Tomo en préstamo las expresiones empleadas por FERNÁNDEZ RODRÍGUEZ, T.R. (2013: 78 y 93 y $2017: 139$ y ss.).

${ }_{55}$ Vid. FERNÁNDEZ RODRÍGUEZ, T.R., (2013: 93); asimismo, MEDINA ALCOZ, L., "Libertad y autoridad en el derecho administrativo: derecho subjetivo e interés legítimo, una revisión", Marcial Pons, Madrid, $1^{\mathrm{a}}$ ed., 2016. Añade aquél que "mi experiencia, ya larga, me lleva a la profunda convicción de que la acción pública en materia de urbanismo no solo no ha aportado nada positivo, sino que ha contribuido a normalizar la corrupción, porque ha propiciado la aparición de personas que han hecho de ella una profesión" [Vid. FERNÁNDEZ RODRÍGUEZ, T.R. (2017: 158)].

Recuérdese que el Código de Urbanismo francés impone desde su reforma parcial de 2013-2014 varias limitaciones en materia de legitimación activa, temporales unas y materiales otras, con el fin de exigir cuando menos la titularidad de un interés legítimo, cuando no un interés directo. Vid. sobre el tema, FERNÁNDEZ RODRÍGUEZ, T.R. (2017: 142 y 158).

56 Vid. FERNÁNDEZ RODRÍGUEZ, T.R. (2017: 155); y GARGIA LUENGO, J. "Las infracciones formales como causa de invalidez del acto administrativo", cit., pág. 103. El Profesor Fernández Rodríguez argumenta más adelante que "esto es tanto más necesario cuanto más compleja es dicha decision y lo es en grado máximo cuando el objeto de la misma es la aprobación de un plan urbanístico, ya sea de ordenación territorial o de ordenación urbana, porque en estos casos y de modo especial en el último de ellos hay miles, docenas de miles de determinaciones muy diferentes entre sí, que se proyectan sobre puntos muy distintos y muy alejados unos de otros dentro de un territorio muy extenso. Esa exigencia de concreción es muy importante, además, porque la valoración del vicio o defecto denunciado no puede ser nunca el resultado puro y simple de la aplicación mecánica de una norma legal, que se limita por su generalidad a indicar la dirección que hay que seguir, pero que no impone en absoluto hasta donde hay que llegar en todo caso. La valoración tiene que hacerse siempre a la vista de las circunstancias del caso". 
2) la atribución a los Jueces y Tribunales de una potestad para suspender la tramitación del proceso contencioso-administrativo y otorgar un plazo para intentar la subsanación del vicio constatado, cuando ello sea posible (p.e., la falta de motivación suficiente, la omisión de un informe preceptivo o de un trámite, como el de audiencia o el de información pública en el procedimiento de elaboración de disposiciones generales, o incluso la ausencia de respuesta a las alegaciones presentadas en el curso de este último), con audiencia a las partes, "solución que - como subraya el Profesor Fernández Rodríguez- está en la línea de los poderes que la Ley vigente les otorga en sus artículos 33.2, 65.2 y 77 " $\mathrm{LJCA}^{57}$;

3) el otorgamiento a los demandados, en procesos contencioso-administrativos promovidos contra disposiciones generales o actos de concesión de títulos habilitantes en todo caso, de una facultad para presentar conclusiones reconvencionales de naturaleza indemnizatoria que persigan, uno, la condena de los demandantes abusivos en el supuesto de desestimación de los recursos y, dos, la reparación de los daños y perjuicios irrogados a aquéllos a resultas de su interposición ${ }^{58}$;

4) la depuración de los privilegios antedichos que carecen de justificación objetiva hoy día;

5) el reconocimiento expreso de instrumentos tales como el principio de intangibilidad de la obra pública, en términos análogos a los previstos en el Derecho francés ${ }^{59}$. Esto es, no debe entenderse como una pura y simple

57 Vid. FERNÁNDEZ RODRÍGUEZ, T.R. (2013: 94; 2017: 154 y ss. y 160-161).

58 El Profesor Fernández Rodríguez vaticina que la implantación de tal medida supondría que "los profesionales de la acción pública desaparecerían con toda seguridad del escenario" (vid. 2013: 94). La experiencia acumulada lo hace más que probable, como deja patente el asunto en Francia (vid. FERNÁNDEZ RODRÍGUEZ, T.R. (2017: 142-143 y 159).

59 Vid. al respecto, BARCELONA LLOP, J., "La obra pública y su protección jurídica en Francia. En especial, el principio de intangibilidad (Ouvrage public mal planté ne se détruit pas)", Revista de Administración Pública (2001) 154, págs. 463-499; del mismo autor, "Nuevas tribulaciones del principio de intangibilidad de la obra pública en Francia", Revista de Administración Pública (2001) 164, págs. -; FERNÁNDEZ TORRES, J.R., "Compromisos y desafios de la Justicia administrativa en el marco de un nuevo Derecho administrativo", en SÁNCHEZ BLANCO, A., DOMÍNGUEZ-BERRUETA DE JUAN, M. y RIVERO

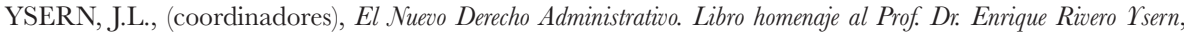
Universidad de Salamanca y Ratio Legis, Salamanca, Salamanca, 1ª ed., 2012, págs. 147-164; y sobre la existencia de fórmulas e instrumentos análogos en el pasado en el ordenamiento urbanístico español tales como el artículo 228 de la Ley del Régimen del Suelo y Ordenación Urbana de 1956 y la posibilidad de su reimplantación corregido, FERNÁNDEZ RODRÍGUEZ, T.R. (2013: 82-83 y 94-95).

Lo que sugiere este último autor es "recentrar la demolición restringiendo su aplicación a los casos de construcciones realizadas sin permiso o en zonas protegidas por razones patrimoniales o ambientales en sentido amplio (la banda litoral en una extensión de cien metros, los espacios naturales protegidos, los 
prerrogativa administrativa en virtud de la cual sea imposible jurídicamente que un Juez o Tribunal ordene la destrucción, modificación o desplazamiento de la obra pública aunque sea ilegal. Debe concebirse más bien como una obligación del Juez o Tribunal de indagar, en primer lugar, si cabe una regularización apropiada de la obra pública y, de no ser posible, en segundo lugar, evaluar por un lado las desventajas de su presencia para todos los intereses concurrentes, y en particular para los del propietario de los terrenos en los que se ubique, y, por otro, los efectos negativos de su demolición para el interés general, y en especial su carácter desproporcionado ${ }^{60}$. Se trata, como pretende en el curso de los últimos años el Consejo de Estado francés, de modular el alcance de las prerrogativas judiciales y garantizar así la efectividad del principio de intangibilidad de la obra pública, en especial cuando el interés general exige preservarla en atención a sus características y dimensiones ${ }^{61} ; \mathrm{y}$

6) el robustecimiento de los deberes de información a cargo de todos los operadores (en el ámbito del urbanismo, el enajenante, el Ayuntamiento y

sectores incluidos en los planes de prevención de riesgos, los perímetros de las servidumbres relativas a los suelos contaminados, los bienes de interés cultural, etc.)", sirviéndose de una reformulación revisada del "viejo artículo 228 de la Ley del Suelo de 1956 de forma que en casos como los más atrás comentados el Juez o Tribunal de la ejecución pudiera dirigirse a la Administración para que en el plazo de dos meses manifestara si, por razones de interés público debidamente justificadas, considera procedente seguir o conservar las obras. De la manifestación correspondiente se daría traslado a las partes y, a la vista de todo ello, el Juez o Tribunal resolvería finalmente lo que considerase oportuno". De esta forma, "nos ahorraríamos el espectáculo vergonzante de unas Sentencias muy rigurosas que, sin embargo, se quedan en una suerte de limbo, pues ni se ejecutan, ni se puede declarar formalmente que su ejecución es legalmente imposible porque no se dan los requisitos que la jurisprudencia dominante considera imprescindibles para formular dicha declaración". Vid. asimismo, a propósito del principio de regularización impulsado por la reciente reforma del Código de Urbanismo francés, FERNÁNDEZ RODRÍGUEZ, T.R. (2017: 143-145 y 159-160).

60 Tal como señala el Consejo de Estado francés en fallos como el de 13 de febrero de 2009 (Communauté de communes du Canton de Saint-Malo de la Lande), recae sobre el Juez o Tribunal la obligación, en todo caso, de

"buscar, primero, si a la vista en particular de la naturaleza de la irregularidad, es posible una regularización apropiada; que, en caso negativo, le corresponde a continuación tomar en consideración, por una parte, los inconvenientes que la presencia de la obra implica para los diferentes intereses públicos o privados que están en presencia y, en especial en su caso, para el propietario del terreno donde se ubica aquélla y, por otra, las consecuencias de la demolición para el interés general, y apreciar, aproximando estos elementos, si la demolición no conlleva un perjuicio excesivo para el interés general» (sic)".

${ }_{61}$ Vid. FERNÁNDEZ TORRES, J.R., "Confirmación de la sujeción de los proyectos de obras en vías urbanas, como la reforma de la M-30, a evaluación de impacto ambiental (comentario a la SSTSJ de Madrid de 11 de febrero de 2011)", Revista Aranzadi de Urbanismo y Edificación (2011) 23, págs. 115-121. 
cualesquiera otras Administraciones competentes para el otorgamiento de otros títulos habilitantes ${ }^{62}$.

En tercer y último lugar, resulta preciso un esfuerzo serio, y no meramente aparente, de racionalización del ejercicio de las potestades normativas, que frene los excesos reglamentistas y simplifique los procedimientos de toma de decisión, en ciertos sectores como el urbanístico en todo caso (los instrumentos de planeamiento y las licencias lo precisan indubitadamente $)^{63}$.

Estos son los retos y desafíos que urge afrontar con una voluntad decidida para que la Justicia administrativa siga desempeñando su papel de garante fundamental del Estado de Derecho y de eficaz protector de los derechos fundamentales y las libertades públicas ${ }^{64}$.

62 Vid. MENÉNDEZ PÉREZ, S. (2004: 123-125).

63 Vid. FERNÁNDEZ RODRÍGUEZ, T.R. (2013: 92).

64 Vid. GARCÍA DE ENTERRÍA, E., Las Transformaciones de la Fusticia Administrativa: de Excepción Singular a la Plenitud Furisdiccional. ¿ Un cambio de Paradigma?, Civitas Thomson, Madrid, $1^{a}$ ed., 2007, pg. 145; y FERNÁNDEZ TORRES, J.R. (2012: 149). 